\title{
Komposisi dan Kelimpahan Ophiuroidea dan Echinoidea di Perairan Pantai Pok Tunggal, Gunung Kidul, Yogyakarta
}

\author{
Herlina Lestari Pakpahan, Irwani, Ita Widowati \\ Departemen IImu Kelautan, Fakultas Perikanan dan Ilmu Kelautan, Universitas Diponegoro \\ JI. Prof.H.Soedarto S.H, Tembalang,Semarang, Jawa Tengah 50275 Indonesia \\ ${ }^{*}$ Corresponding author, e-mail : herlinalestaripakpahan@gmail.com
}

\begin{abstract}
ABSTRAK: Echinodermata merupakan salah satu komponen penting dalam keaneka ragaman fauna di ekosistem pantai. Habitat utama echinodermata adalah terumbu karang, hal ini karena terumbu karang berperan sebagai tempat berlindung dan mencari makan bagi fauna echinodermata. Salah satu penyebaran biota ini adalah di perairan rataan terumbu karang pantai selatan di pantai Pok Tunggal, Gunung Kidul, Yogyakarta. Tujuan penelitian ini adalah untuk mengetahui jenis dan struktur komunitas echinodermata di pantai Pok Tunggal, kabupaten Gunung Kidul, Yogyakarta. Penelitian ini dilaksanakan pada bulan Juli 2019 di pantai Pok Tunggal. Metode pengambilan data kelimpahan menggunakan metode transek kuadrat berukuran $1 \times 1 \mathrm{~m}$, parameter kualitas perairan yang diukur adalah salinitas, $\mathrm{DO}, \mathrm{pH}$, serta suhu. Analisis data meliputi identifikasi spesies, kelimpahan jenis $\left(\mathrm{ind} / \mathrm{m}^{2}\right)$, indeks keanekaragaman, indeks keseragaman dan indeks dominansi. Hasil pengamatan ditemukan beberapa spesies, dari 2 kelas filum echinodermata, antara lain 2 species dari kelas Ophiuroidea yaitu Ophiocoma erinaceus dan Ophiocoma dentata, 3 species dari kelas Echinoidea yaitu Echinometra oblonga, Echinometra mathei dan Echinothrix diadema. Hasil penelitian menunjukkan kelimpahan individu tertinggi adalah Echinometra oblonga $\left(16,6 \mathrm{ind} / \mathrm{m}^{2}\right)$ dan terendah adalah Echinothrix diadema $\left(0,4 \mathrm{ind} / \mathrm{m}^{2}\right)$. Parameter lingkungan perairan di pantai Pok Tunggal pada setiap stasiun masih menunjang kehidupan Echinodermata. Struktur komunitas echinodermata yaitu nilai indeks keanekaragaman $(H)$ berkisar antara 0,667-1,198, nilai indeks keseragaman (E) berkisar antara 0,744 - 0,999 dan nilai indeks dominansi $(C)$ berkisar berkisar 0,308 - 0,525.
\end{abstract}

Kata kunci : Echinodermata; Struktur Komunitas; Pantai Pok Tunggal

\section{Community Structure of Brittle Star (Ophiuroidea) and Sea Urchin (Echinoidea) in Pok Tunggal Beach Waters, Gunung Kidul, Yogyakarta}

ABSTRACT: Echinoderms are one of important component of fauna diversity in coastal ecosystems. The main habitat of Echinoderms is coral reefs, because coral reefs act as a shelter and food for echinoderms fauna. This species distributed in the flat waters of the coral reefs of the south coast at Pok Tunggal beach, Gunung Kidul, Yogyakarta. The aim of this study was to determine the species and Community Structure of echinoderms on the Pok Tunggal beach, Gunung Kidul Regency, Yogyakarta. This research was conducted in July 2018 at Pok Tunggal Beach. Sampling was done by using transect quadrant measuring $1 \times 1 \mathrm{~m}$. Parameter of water quality was salinity, $\mathrm{DO}, \mathrm{pH}$, and temperature. Data analysis includes species abundance $\left(\mathrm{ind} / \mathrm{m}^{2}\right)$, diversity index, uniformity index and dominance index. The result showed that several species of Echinodermal phylum classes, including 2 species of Ophiuroidea class namely Ophiocoma erinaceus and Ophiocoma dentata, 3 species of Echinoidea class namely Echinometra oblonga, Echinometra mathei and Echinothrix diadema. The highest individual abundance was Echinometra oblonga $\left(16,6 \mathrm{ind} / \mathrm{m}^{2}\right)$ and the lowest was Echinothrix diadema $\left(0,4 \mathrm{ind} / \mathrm{m}^{2}\right)$. The environmental conditions of the waters at the Pok Tunggal beach at each station can support the life of echinoderms. Echinoderms community structure, namely diversity index $(H$ ') ranges from 0,6671,198 , uniformity index $(E)$ ranges from $0,744-0,999$ and dominance index value ranges $(C)$ ranges from 0,308-0,525.

Keywords: Echinoderms; Community Structure; Pok Tunggal Beach 


\section{PENDAHULUAN}

Kawasan ekosistem pantai Pok Tunggal merupakan kawasan pariwisata yang memiliki kelimpahan dan keanekaragaman biota laut yang beragam. Ekosistem laut dihuni oleh berbagai jenis invertebrata diantaranya seperti Coelenterata, Mollusca, Annelida, dan Echinodermata. Echinodermata berasal dari bahasa Yunani yaitu Echinus berarti landak, dan derma berarti kulit. Semua jenis Echinodermata hidup di laut, mulai dari daerah litoral sampai kedalaman 6.000 meter. Filum Echinodermata antara lain bintang laut, bulu babi, teripang yang pada umumnya berukuran besar dan yang terkecil berdiameter $1 \mathrm{~cm}$ (Brotowidjoyo, 1994). Echinodermata merupakan hewan invertebrata yang hanya dapat hidup di perairan laut. Echinodermata memiliki peranan penting bagi ekosistem laut. Echinodermata berperan sebagai hewan pemakan sampah organik baik itu berupa sisa hewan ataupun tumbuhan sehingga keberadaannya berguna untuk membersihkan lautan dari sampah organik. Kelompok Echinodermata dapat hidup menempati berbagai macam habitat seperti zona rataan terumbu, daerah pertumbuhan alga, padang lamun, koloni karang hidup dan karang mati dan beting karang (Yusron, 2009).

Echinodermata merupakan salah satu komponen penting dalam hal keanekaragaman fauna di daerah terumbu karang, hal ini karena terumbu karang berperan sebagai tempat berlindung dan tempat makan bagi fauna Echinodermata. Echinodermata berperan sangat penting dalam ekosistem terumbu karang, terutama dalam rantai makanan (food chains) (Yusron, 2010). Ekosistem Pantai dipengaruhi oleh faktor biotik maupun abiotik. Keberadaan suatu organisme khususnya Echinodermata dapat diukur dari faktor lingkungan yang terdapat di kawasan pantai Pok Tunggal. Faktor lingkungan tersebut yaitu suhu air, dissolved oxygen (DO), salinitas, dan $\mathrm{pH}$ air. Selain faktor lingkungan, aktifitas manusia dapat berpengaruh terhadap keberlangsungan organisme khususnya komunitas Echinodermata. Sehubungan dengan meningkatnya aktifitas manusia yang berkunjung dan berekreasi ke pantai Pok Tunggal Gunung Kidul Yogyakarta maka tanpa disadari ekosistem biota hewan laut khususnya hewan Echinodermata mulai terancam. Pantai masih terlihat alami, tetapi ekosistem pada zona litoral pantai Pok Tunggal ini sudah tersentuh oleh aktifitas manusia salah satunya ekosistem terumbu karang.

Penelitian sebelumnya mengenai struktur komunitas Echinodermata di pantai selatan Yogyakarta dilakukan di pantai Kukup pantai Krakal, pantai Drini, pantai Sepanjang dan pantai Sundak (Yusron, 2015; Nugroho et al., 2017; Triatmojo et al., 2018; Putri et al., 2019). Dari hasil pengamatan dan koleksi pada lima lokasi penelitian didapatkan duabelas jenis Echinodermata dari tiga kelas fauna Echinodermata yaitu Holothuria scabra, $H$. atra, $H$. hilla, $H$. leucospilota dari kelas Holothuroidea. Echinometra mathaei, Echinothrix calamaris, Heterocentrotus trigonarius, Tripneutes gratilla dari kelas Echinoidea dan dari kelas Ophiuroidea terdapat empat jenis yaitu Ohiomastix annulosa, Ophiarthrum elegans, Ophiomastix variabilis, Ophiothrix fumaria. Penelitian yang dilakukan oleh Suwartimah et al., (2017) di pantai Krakal ditemukan 3 jenis bintang mengular yaitu Ophiocoma erinaceus, Ophiocoma riisei, dan Ophiocoma scolopendrina dan untuk bulu babi ditemukan 3 spesies yaitu Echinometra mathaei, Echinometra oblonga, dan Echinometra viridis. Struktur komunitas Echinodermata di pantai Indrayanti oleh Nugroho et al., (2017) ditemukan sebanyak 2 jenis Echinodermata yaitu bulu babi dan bintang mengular. Spesies bulu babi yang ditemukan ada 3 jenis yaitu Stomopneustes sp, Echinometra sp, dan Echinometra mathaei. Spesies bintang mengular yang ditemukan ada 2 jenis yaitu Ophiocoma erinaceus dan Ophiocoma scolopendrina.

Penelitian sebelumnya yang dilakukan menunjukkan bahwa terjadi penurunan jenis Echinodermata yang ditemukan, hal ini diduga disebabkan meningkatnya jumlah wisatawan yang berkunjung ke pantai Selatan. Meningkatnya pengunjung wisata dapat menjadi ancaman kerusakan habitat Echinodermata yang dapat mengakibatkan menurunnya populasi Echinodermata di pantai tersebut. Pantai Pok Tunggal merupakan salah satu obyek wisata alam yang banyak dikunjungi oleh wisatawan yang datang ke Yogyakarta. Sampai saat ini belum ada data mengenai struktur komunitas Echinodermata di perairan pantai Pok Tunggal, sedangkan perairan tersebut banyak dikunjungi wisatawan. Aktivitas masyarakat yang tinggi baik secara langsung maupun tidak langsung akan mempengaruhi kualitas lingkungan perairan di perairan pantai Pok Tunggal. Hal ini diperkuat oleh penelitian yang dilakukan oleh Syafrijal et al., (2019) di Perairan Deudap Pulau Aceh Besar yang menyatakan bahwa keanekaragaman Echinodermata 
menurun karena perairan yang dijadikan sebagai tempat wisata dan tempat bersandar kapal nelayan. Kualitas lingkungan perairan akan mempengaruhi keanekaragaman dan struktur komunitas dari organisme yang hidup di dasar perairan tersebut (Budiman, 2014).

\section{MATERI DAN METODE}

Penelitian ini dilaksanakan pada bulan Juli 2019 di perairan pantai Pok Tunggal kecamatan Tepus, kabupaten Gunung Kidul, D.I. Yogyakarta. Materi yang diamati dalam penelitian ini adalah bintang mengular dan bulu babi yang terdapat pada lokasi penelitian pantai Pok Tunggal kecamatan Tepus, kabupaten Gunung Kidul, D.I. Yogyakarta. Data parameter kualitas air yang diukur berupa salinitas, suhu, DO dan $\mathrm{pH}$. Metode yang digunakan dalam penelitian ini adalah metode deskriptif, dimana metode yang digunakan akan dapat mendeskripsikan keadaan lokasi tersebut. Menurut Notoatmodjo (2002), dalam metode deskriptif, penelitian tidak dilakukan pada seluruh objek yang dikaji, tetapi hanya mengambil dari populasi (sampel). Metode deskriptif, merupakan penelitian yang dilakukan dengan tujuan membuat gambaran suatu keadaan secara objektif. Metode yang digunakan dalam pemilihan lokasi sampling yaitu metode observasi lapangan. Sebelum melakukan sampling lapangan, dilakukan terlebih dahulu pemilihan tempat penelitian yang sesuai dengan habitat echinodermata (Aziz, 1996). Metode yang digunakan dalam penentuan lokasi adalah purposive sampling yang dibagi menjadi 3 stasiun dengan 3 kali pengulangan berdasarkan keterwakilan karakteristik yang berbeda di lokasi penelitian. Stasiun 1 ( $8^{\circ} 09^{\prime} 23^{\prime \prime} S$ dan $110^{\circ} 37^{\prime 2} 21^{\prime \prime E}$ ) memiliki kondisi

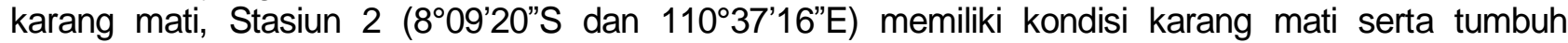
beberapa jenis rumput laut, Stasiun 3 ( $8^{\circ} 09^{\prime} 17^{\prime \prime} S$ dan $\left.110^{\circ} 37^{\prime} 12^{\prime \prime} E\right)$ memiliki kondisi yang didominasi karang hidup.

Pengambilan sampel dilakukan pada saat air surut pada jam 15.00-17.30 WIB. Pengambilan sampel dilakukan pada saat surut karena pantai Pok Tunggal berlokasi di pantai Selatan Pulau Jawa dan menghadap langsung ke Samudera Hindia, menjadikan pantai ini memiliki gelombang yang cukup besar saat pasang. Pengambilan sampel dilakukan dengan menggunakan metode transek kuadrat pada tiga stasiun. Terdapat tiga transek yang telah ditentukan pada setiap stasiun dengan jarak 15 meter. Pada setiap transek ditarik garis lurus dari titik surut terendah menuju tubir sepanjang 50 meter dengan menggunakan roll meter. Dalam satu transek terdapat lima plot $1 \times 1 \mathrm{~m}$, jarak antar plot yaitu 10 meter. Data penunjang pada penelitian ini merupakan faktor klimatik

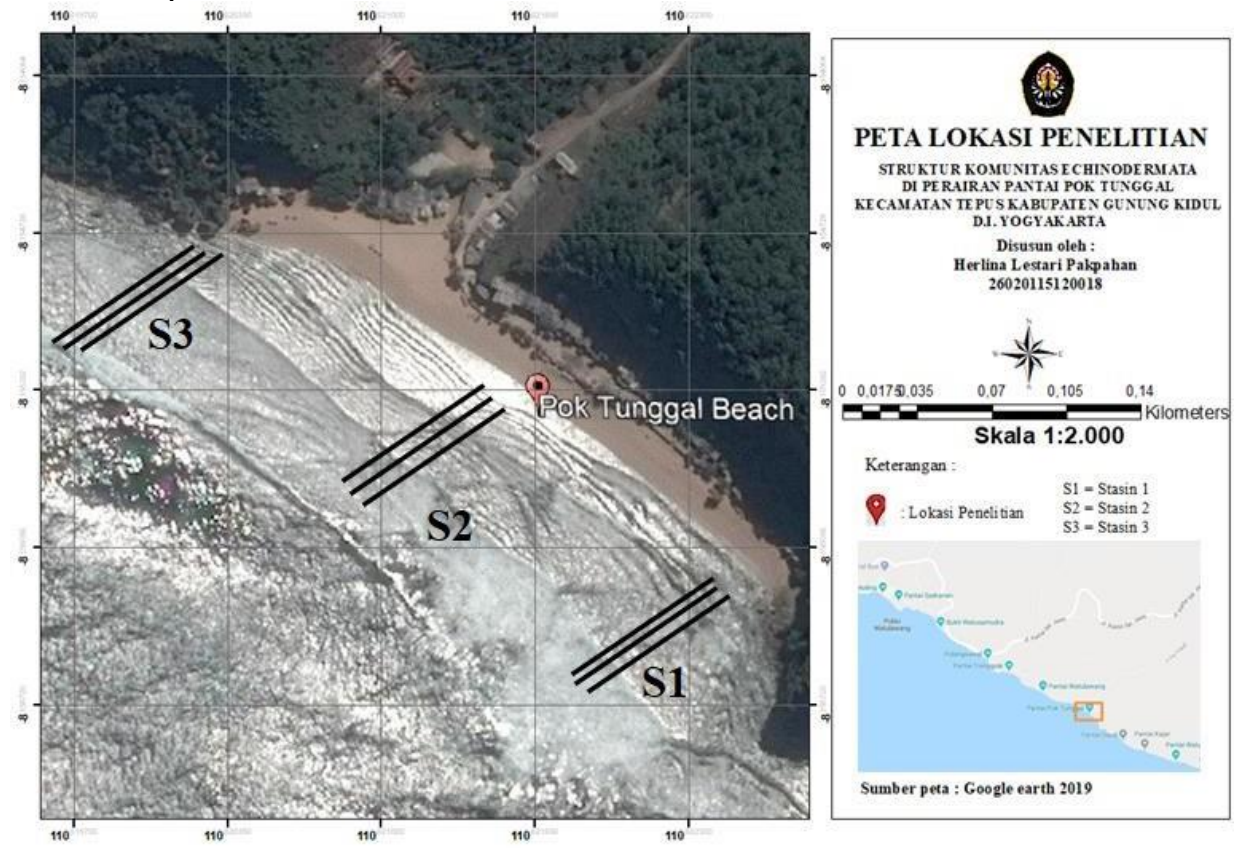

Gambar 1. Titik Sampling Lokasi Penelitian 
seperti suhu air, kandungan ion hidrogen $(\mathrm{pH})$, salinitas air dan oksigen terlarut (Dissolved Oxygen). Pengukuran faktor lingkungan tersebut dilakukan di setiap titik kuadrat. Pengukuran suhu air dan oksigen terlarut (Dissolved Oxygen) menggunakan DO meter yang sudah otomatis dapat menghitung suhu air, dengan cara mencelupkan DO meter ke dalam air yang akan diukur kandungan oksigen dan suhu airnya kemudian biarkan lima menit. Pengukuran kandungan ion hidrogen $(\mathrm{pH})$ menggunakan $\mathrm{pH}$ meter dengan cara mencelupkan $\mathrm{pH}$ meter pada air yang akan diukur serta untuk mengukur salinitas menggunakan refraktometer manual.

Proses identifikasi dilakukan dengan cara mengamati morfologi sampel secara langsung. Pengamatan karakter morfologi seperti bentuk lengan dan warna untuk kelas Ophiuroidea (Triana et al., 2015). Pengamatan bentuk dan warna ambulakral untuk kelas Echinoidea (Fell, 1960). Untuk mengetahui data klasifikasi echinodermata yang terdapat pada Pok Tunggal Gunung Kidul Yogyakarta organisme yang diperoleh dari pengambilan sampel, diidentifikasi dengan buku yang berjudul A Guide to Common Echinoderms of Andaman and Nicobar Islands (Raghunathan, 2013).

Kelimpahan jenis adalah jumlah individu per satuan luas. Kelimpahan masing-masing jenis pada setiap stasiun dihitung dengan menggunakan rumus Odum (1971). Data Kelimpahan relatif echinodermata di Pantai Pok Tunggal Gunung Kidul Yogyakarta dihitung dengan menggunakan rumus yang diadopsi dari Krebs (1989). Keanekaragaman echinodermata di Pantai Pok Tunggal Gunung Kidul Yogyakarta dihitung dengan menggunakan rumus menurut Shannon Wiener (1998)

Besarnya indeks keanekaragaman jenis menurut Shannon Wiener didefinisikan sebagai berikut: Nilai $\mathrm{H}^{\prime}>3$ menunjukan bahwa keanekaragaman spesies pada suatu transek adalah melimpah tinggi. Nilai $H^{\prime} 1 \leq 3$ menunjukan bahwa keanekaragaman spesies pada suatu transek adalah sedang. Nilai $H^{\prime}<1$ menunjukan bahwa keanekaragaman spesies pada suatu transek adalah sedikit atau rendah.Data keseragaman echinodermata di Pantai Pok Tunggal Gunung Kidul Yogyakarta dihitung dengan menggunakan rumus menurut Pielou. Menurut Krebs (1989), besarnya indeks keseragaman jenis berkisar antara 0 sampai dengan $1 . E<0,4$ : Keseragaman jenis rendah; 0,4 $<E<0,6$ : Keseragaman jenis sedang; $E>0,6$ : Keseragaman jenis tinggi. Indeks dominasi organisme Echinodermata dihitung dengan menggunakan rumus (Odum, 1993). Indeks dominansi dapat dikelompokkan menjadi : $\mathrm{C}<0.4$ : Dominansi Rendah; $0.4<\mathrm{C}<$ 0.6 : Dominansi Sedang; C > 0.6 : Dominansi Tinggi.

\section{HASIL DAN PEMBAHASAN}

Pantai Pok Tunggal dibuka oleh masyarakat setempat menjadi sebuah objek wisata pantai di Gunung Kidul sejak tahun 2012. Pantai ini berada di desa Tepus, kecamatan Tepus, kabupaten Gunung Kidul, Daerah Istimewa Yogyakarta. Pantai Pok Tunggal berlokasi di selatan Pulau Jawa dan menghadap langsung ke Samudera Hindia, menjadikan pantai ini memiliki gelombang yang cukup besar pada saat pasang. Pantai ini memiliki panorama yang indah dengan hamparan pasir putih, pantai landai serta adanya perbukitan karst. Pada sisi Timur dan Barat pantai ini diapit oleh tebing-tebing karang yang menjulang. Pantai Pok Tunggal memiliki karakteristik yang sama seperti pantai lainnya di daerah selatan pulau Jawa dengan lautnya yang berarus kencang dan batuan karst yang menyusun daratannya.

Echinodermata yang ditemukan di ekosistem pantai Pok Tunggal, Gunung Kidul, Yogyakarta diperoleh 5 jenis Echinodermata dari 2 kelas yang berbeda yaitu kelas Ophiuroidea terdiri dari 2 jenis meliputi Ophiocoma erinaceus dan Ophiocoma dentata, kelas Echinoidae terdiri dari 3 jenis yaitu Echinometra oblonga, Echinometra mathaei dan Echinothrix diadema. Jenis Echinodermata yang paling banyak ditemukan adalah Echinometra oblonga dan pengamatan menunjukkan bahwa echinodermata lebih banyak ditemukan di stasiun 2 dibanding stasiun yang lain, hal ini karena stasiun 2 didominasi karang mati dan ditumbuhi banyak rumput laut. Hal ini disebabkan karena pola makan bulu babi yang merupakan herbivora dan memakan alga (Suryanti dan Frida, 2014). Kelas Ophiouroidea dan Kelas Echinoidea hampir ditemukan di setiap stasiun pengambilan sampel, stasiun dan titik pengamatan. Kebanyakan anggota kelas Ophiuroidea dan Echinoidea dalam penelitian ini dijumpai bersembunyi di balik atau di antara tumpukan batu dan pecahan karang. Menurut Aziz (1996), kelas Ophiouroidea dan kelas Echinoidea bersembunyi pada beting karang untuk menghindari kekeringan saat surut dan sinar matahari. Saat perairan mengalami surut terendah, pada stasiun 1 dan stasiun 3 banyak ditemukan aktivitas pengunjung, 
karena dekat dengan perbukitan karst dan banyak tebing karang yang menjulang tinggi yang menarik perhatian wisatawan. Hal ini diduga memberikan pengaruh terhadap komposisi species Echinodermata pada ketiga stasiun pengamatan tersebut sesuai dengan pernyataan Damayanti dan Ayuningtyas (2008), yaitu pemanfaatan pantai karst di Kabupaten Gunung Kidul secara umum difungsikan untuk kegiatan pariwisata.

Penelitian yang dilakukan oleh Yusron (2015) di pantai Kukup, pantai Krakal, pantai Drini, pantai Sepanjang dan pantai Sundak. Dari hasil pengamatan dan koleksi pada lima lokasi penelitian didapatkan dua belas jenis Echinodermata dari tiga kelas fauna Echinodermata. Jenis yang sama didapatkan di pantai pok tunggal hanya satu jenis yaitu Echinometra mathaei. Penelitian pada bulan Maret 2015 yang dilakukan di Pantai Krakal oleh Suwartimah et al. (2017) Spesies yang ditemukan rata-rata ditemukan pada penelitian ini, kecuali Archaster typicus, Echinometra viridis, Ophiocoma scolopendrina, Ophiocoma riseii dan Ophiarachna affinis. Perbedaan hasil temuan yang didapatkan dapat disebabkan oleh ekosistem yang berbeda yaitu ekosistem lamun sedangkan di pantai Pok Tunggal didominansi karang mati. Kedua penelitian dilakukan pada musim kemarau dibulan maret dan juli, adanya perbedaan spesies yang ditemukan diduga diakibatkan waktu penelitian yang sudah berjarak empat dan tujuh tahun, beberapa jenis Echinodermata sudah tidak menempati pantai Selatan.

Arthaz et al. (2015), melakukan penelitian tentang hubungan substrat dengan kelimpahan bulu babi di Pantai Krakal, hasilnya ditemukan 3 spesies bulu babi. Satu diantaranya tidak ditemukan pada penelitian ini yaitu Stomopneustus $s p$ dan terdapat 1 spesies yang ditemukan pada penelitian ini namun tidak ditemukan pada tahun 2014 yaitu E. Diadema. Perbedaan komposisi juga dapat disebabkan perbedaan waktu dan musim sampling. Keberadaan dan kelimpahan Echinodermata di satu lokasi dipengaruhi oleh lingkungan baik faktor biotik dan abiotik yang saling terkait satu dengan yang lain, serta interaksi antara berbagai spesies yang membentuk sistem tersebut. Echinodermata mempunyai cara dan kemampuan berbeda dalam menentukan lokasi yang cocok untuk tempat hidupnya, sehingga perbandingan jenis dan kelimpahan Echinodermata di satu lokasi pada waktu yang berbeda perlu untuk dipelajari (Hadi, 2012).

Kelimpahan Echinodermata di Pantai Pok Tunggal yang tertinggi pada semua stasiun adalah jenis E. oblonga. Hal ini disebabkan karena jenis ini dapat hidup dengan baik pada ekosistem dengan substrat berpasir, lubang bebatuan dan pecahan karang mati yang terdapat pada lokasi penelitian. Selain itu dapat beregenerasi dengan cepat, sehingga jenis ini memiliki kelimpahan relatif yang tinggi di perairan (Brusca et al., 2003). Sedangkan yang terendah adalah E. mathei dan E. diadema Hal ini dikarenakan kedua jenis ini merupakan bulu babi yang bisa dikonsumsi (Aziz, 1993). Kelimpahan tertinggi pada lokasi penelitian yaitu terdapat pada stasiun 2 dengan kelimpahan sebesar $29,8-38,4 \mathrm{ind} / \mathrm{m}^{2}$ dengan jumlah jenis yang paling banyak dijumpai yaitu sebanyak 5 jenis. Hal ini disebabkan karena adanya penutupan rumput laut pada stasiun ini sehingga banyak terdapat serasah yang dapat dijadikan sumber makanan bagi biota di daerah tersebut dan DO di stasiun ini lebih tinggi dibanding dengan stasiun 1 dan 3 . Tinggi rendahnya kelimpahan suatu organisme sangat dipengaruhi oleh berbagai faktor lingkungan di sekitarnya, salah satu faktor yang sangat berpengaruh yaitu ketersediaan makanan dan oksigen yang cukup.

Kelimpahan Echinodermata yang terendah pada lokasi penelitian yaitu terdapat pada stasiun 3 dengan kepadatan sebesar $8,2-9,8 \mathrm{ind} / \mathrm{m}^{2}$. Hal ini diduga karena adanya aktivitas wisatawan dan pemanfaatan yang berlebihan oleh masyarakat setempat sehingga mengakibatkan berkurangnya populasi Echinodermata pada stasiun ini. Hal ini sesuai dengan pernyataan Damayanti dan Ayuningtyas (2008) yang menyatakan bahwa menurunnya kepadatan Echinodermata disebabkan oleh aktivitas pengunjung didekat bukit karst yang paling dekat dengan stasiun 3. Selain itu faktor lain yang mempengaruhi rendahnya nilai kepadatan dari Echinodermata salah satunya disebabkan karena penangkapan secara terus-menerus oleh masyarakat untuk dijadikan bahan konsumsi dan perdagangan (Budiman et al., 2014). Kelimpahan relatif bulu babi dan bintang mengular yang ditemukan, didapatkan nilai yang paling tinggi pada jenis E.oblonga dan $O$. Erinaceus. Nilai ini menunjukkan bahwa kedua jenis ini dapat hidup dengan baik di perairan pantai pok tunggal. 
Tabel 1. Komposisi Jenis bintang mengular dan bulu babi di Pantai Pok Tunggal

\begin{tabular}{lcccccccccc}
\hline \multirow{2}{*}{ Jenis Echinodermata } & \multicolumn{3}{c}{ Stasiun 1 } & \multicolumn{3}{c}{ Stasiun 2 } & \multicolumn{3}{c}{ Stasiun 3 } \\
\cline { 2 - 11 } & L1 & L2 & L3 & L1 & L2 & L3 & L1 & L2 & L3 \\
\hline Ophiocoma erinaceus & + & + & + & + & + & + & + & + & + \\
Ophiocoma dentata & + & + & + & + & + & + & - & - & - \\
Echinometra oblonga & + & + & + & + & + & + & + & + & + \\
Echinometra mathaei & - & - & - & - & + & + & - & - & - \\
Echinothrix diadema & - & - & - & + & - & + & - & - & - \\
Jumlah Spesies & 3 & 3 & 3 & 4 & 4 & 5 & 2 & 2 & 2 \\
\hline
\end{tabular}

Keterangan : L : Line/ titik sampling (+) : ditemukan; (-) : tidak ditemukan

Tabel 2. Kelimpahan Jenis Echinodermata di Pantai Pok Tunggal

\begin{tabular}{|c|c|c|c|c|c|c|c|c|c|}
\hline \multirow[t]{2}{*}{ Kelas/ Spesies } & \multicolumn{3}{|c|}{$\begin{array}{c}\text { Stasiun } 1 \\
\text { (individu/m } / \mathrm{m}^{2} \text { ) }\end{array}$} & \multicolumn{3}{|c|}{$\begin{array}{c}\text { Stasiun } 2 \\
\text { (individu/m²) }\end{array}$} & \multicolumn{3}{|c|}{$\begin{array}{c}\text { Stasiun 3 } \\
\text { (individu/m²) }\end{array}$} \\
\hline & L 1 & L 2 & L 3 & L 1 & L 2 & L 3 & L 1 & L 2 & L 3 \\
\hline \multicolumn{10}{|l|}{ Ophiuroidea } \\
\hline O. erinaceus & 6 & 4,8 & 7,2 & 11,2 & 9,4 & 13 & 4 & 4,6 & 3,8 \\
\hline O. dentata & 5 & 5,8 & 4,2 & 6,6 & 6,2 & 7,2 & - & - & - \\
\hline \multicolumn{10}{|l|}{ Echinoidea } \\
\hline E. oblonga & 11,4 & 10,6 & 14,4 & 16 & 14,2 & 16,6 & 4,2 & 5 & 6 \\
\hline E. mathaei & - & - & - & - & 0.8 & 1,2 & - & - & - \\
\hline E. diadema & - & - & - & 0,6 & - & 0,4 & - & - & - \\
\hline Jumlah Individu & 22,4 & 21,2 & 25,8 & 34,4 & 29,8 & 38,4 & 8,2 & 9,6 & 9,8 \\
\hline
\end{tabular}

\section{Indeks Keanekaragaman, Keseragaman dan Dominansi}

Berdasarkan data yang telah diperoleh, diketahui bahwa Indeks Keanekaragaman $\left(\mathrm{H}^{\prime}\right)$ Echinodermata di stasiun 1 yaitu sebesar $0,977-1,037$; stasiun 2 sebesar 1,137-1,198 dan stasiun 3 sebesar 0,667-0,692 . Nilai terendah $\mathrm{H}$ ditemukan pada stasiun 3 yakni 0,667, hal ini diduga karena stasiun ini merupakan daerah dengan didominasi karang hidup dan paling dekat dengan bukit karst di pantai Pok Tunggal dimana pengunjung banyak menggunakan wilayah bukit karst di pantai. Nilai $\mathrm{H}$ tertinggi terdapat pada stasiun 2 yang didominasi karang mati, hal ini disebabkan karena pantai pok tunggal menghadap langsung dengan laut selatan, sehingga ombak yang kuat membuat bulu babi dan bintang mengular lebih banyak ditemukan di pecahan karang untuk melindungi diri.

Indeks Keseragaman (E) setiap stasiun cukup berbeda. Nilai pada stasiun 1 yaitu 0,8890,944 , stasiun 2 yaitu $0,744-0,845$ dan stasiun 3 yaitu $0,963-0,999$. Nilai keseragaman setiap stasiun menunjukkan bahwa indeks keseragaman Echinodermata di pantai Pok Tunggal tergolong tinggi. Nilai Indeks keseragaman jika mendekati nilai 0 , maka dalam ekosistem ada kecenderungan terjadinya dominansi spesies yang disebabkan oleh adanya faktor-faktor lingkungan dan populasi. Indeks Dominansi (C) yang diperoleh dari ketiga stasiun penelitian berkisar antara 0,308 - 0,525. Indeks Dominansi tertinggi pada stasiun 3 yaitu sebesar 0,525 dan terendah pada stasiun 1 sebesar 0,308. Dominansi tertinggi di stasiun 3 sebesar 0,525 bernilai sedang dan Indeks Dominansi pada stasiun 1 dan 2 tergolong rendah yang artinya tidak terdapat spesies yang mendominasi spesies lainnya.

Data penelitian di lapangan menunjukkan terjadinya ketidakseimbangan ekosistem hal ini dilihat dengan keberadaan Echinodermata dimana dari 5 kelas Echinodermata ditemukan hanya 2 kelas, dari 2 kelas hanya terdapat 5 species jenis Echinodermata. Hal ini disebabkan ekosistem 
terumbu karang dekat dengan daratan dan pemungkiman rumah warga, pembuangan limbah yang masuk di laut diangkut oleh pasang surut. Perairan Pantai Pok Tunggal juga merupakan salah satu kawasan pariwisata yang dikunjungi banyak orang. Hal ini sesuai dengan hasil penelitian Erlangga et al., 2018 di Pantai Gapang Sabang dimana nilai indeks keseragaman lebih tinggi pada stasiun 1 yaitu 1,46 dibandingkan dua stasiun lainnya, karena stasiun satu merupakan pantai yang paling jarang tersentuh aktivitas manusia.

Panjang zona intertidal suatu perairan juga mempengaruhi nilai indeks keanekaragaman pada struktur komunitas Echinodermata (Suwartimah et al., 2017). Semakin panjang zona intertidal suatu perairan maka memungkinkan semakin besar juga nilai indeks keanekaragaman pada struktur komunitas karena gelombang pasang surut akan lebih kecil sehingga akan makin banyak organisme yang bisa hidup di perairan tersebut. Landai atau terjalnya pantai juga dapat mempengaruhi nilai indeks karena Semakin landai pantainya maka zona intertidalnya semakin panjang. Sebaliknya semakin terjal pantainya maka zona intertidalnya akan semakin sempit (Nybakken, 1992). Hal ini diperkuat oleh penelitian sebelumnya yang dilakukan oleh Suwartimah et al., (2017) di pantai Krakal menunjukkan nilai rata-rata indeks yang lebih tinggi yaitu 1,09 dibandingkan di pantai Pok Tunggal dengan rata-rata 0,95.

Hasil penelitian didapatkan suhu rata-rata perairan pada stasiun 1 berkisar antara 25,1 ${ }^{\circ} \mathrm{C}-27,5{ }^{\circ} \mathrm{C}$, stasiun 2 sebesar $27,5{ }^{\circ} \mathrm{C}-28,1{ }^{\circ} \mathrm{C}$ dan stasiun 3 sebesar $24{ }^{\circ} \mathrm{C}-25,2{ }^{\circ} \mathrm{C}$ dengan suhu tertinggi terdapat pada stasiun 2. Suhu pada ketiga stasiun penelitian masih dapat mendukung bagi kehidupan biota laut. Kondisi Echinodermata cukup sesuai dan stabil karena kisaran suhu tersebut memasuki suhu optimum yaitu $28-34^{\circ} \mathrm{C}$ (Aziz, 1996). Suhu antar stasiun tidak menunjukkan variasi yang besar, perbedaan suhu dapat dipengaruhi oleh kondisi cuaca pada saat

Tabel 3. Indeks Keanekaragaman (H'), Keseragaman (E) dan Dominansi (C) Bintang Mengular dan Bulu Babi di Pantai Pok Tunggal

\begin{tabular}{|c|c|c|c|c|c|c|}
\hline Lokasi/ Line & $\mathrm{H}^{\prime}$ & Kategori & e & Kategori & $\mathrm{D}$ & Kategori \\
\hline \multicolumn{7}{|l|}{ Stasiun 1} \\
\hline 1 & 1,031 & Sedang & 0,938 & Tinggi & 0,308 & Dominansi Rendah \\
\hline 2 & 1,037 & Sedang & 0,944 & Tinggi & 0,376 & Dominansi Rendah \\
\hline 3 & 0,977 & Rendah & 0,889 & Tinggi & 0,415 & Dominansi Sedang \\
\hline \multicolumn{7}{|l|}{ Stasiun 2} \\
\hline 1 & 1,171 & Sedang & 0,845 & Tinggi & 0,359 & Dominansi Rendah \\
\hline 2 & 1,137 & Sedang & 0,820 & Tinggi & 0,351 & Dominansi Rendah \\
\hline 3 & 1,198 & Sedang & 0,744 & Tinggi & 0,337 & Dominansi Rendah \\
\hline \multicolumn{7}{|l|}{ Stasiun 3} \\
\hline 1 & 0,692 & Rendah & 0,999 & Tinggi & 0,5 & Dominansi Sedang \\
\hline 2 & 0,691 & Rendah & 0,998 & Tinggi & 0,5 & Dominansi Sedang \\
\hline 3 & 0,667 & Rendah & 0,963 & Tinggi & 0,525 & Dominansi Sedang \\
\hline
\end{tabular}

Tabel 4. Hasil Pengukuran Kualitas Perairan

\begin{tabular}{lccccc}
\hline \multirow{2}{*}{ Parameter } & \multirow{2}{*}{ Satuan } & \multicolumn{3}{c}{ Stasiun } & \multirow{2}{*}{ Baku Mutu } \\
\cline { 2 - 5 } & & 1 & 2 & 3 & \\
\hline Salinitas & Ppt & $32-35$ & $34-35$ & $31-34$ & $30-34$ (Azis, 1981) \\
Suhu & ${ }^{0} \mathrm{C}$ & $25,1-27,5$ & $27,5-28,1$ & $24-25,2$ & 28-34 (Azis, 1996) \\
DO & $\mathrm{mg} / \mathrm{l}$ & $5,1-5,8$ & $5,9-6,9$ & $4,7-5,2$ & $4-8$ (Martoyo et al., 2006) \\
Ph & - & 8 & 8 & 7 & $7,5-8,6$ (Simatupang et al., 2017) \\
\hline \hline
\end{tabular}


pengukuran. Suhu pada stasiun 3 lebih rendah dibandingkan dengan suhu di kedua stasiun lainnya disebabkan karena pada saat melakukan pengambilan data kondisi cuaca mendung selain itu pengambilan data dilakukan pada sore hari (pukul 15.00 WIB - 17.30 WIB) hal ini sesuai dengan pernyataan Barus (2004) bahwa pola temperatur ekosistem air dipengaruhi oleh beberapa faktor salah satunya intensitas cahaya matahari. Salinitas yang didapat pada penelitian ini berkisar antara 31-35 ppt secara keseluruhan. Stasiun 3 memiliki kisaran salinitas terendah dibandingkan dengan stasiun 1 dan 2. Salinitas berbeda tiap stasiun juga disebabkan perbedaan dari suhu pada setiap stasiun, suhu yang rendah memungkinkan terjadinya penguapan yang rendah begitu juga sebaliknya, sehingga kisaran suhu terendah pada stasiun 3 memiliki nilai salinitas yang lebih rendah dari stasiun 2 dan 3. Ramawijaya et al. (2012) menyatakan bahwa suhu berhubungan langsung dengan salinitas. Suhu yang tinggi mengindikasikan salinitas di tempat tersebut juga tinggi. Hal tersebut karena suhu yang tinggi menyebabkan air laut menguap menyisahkan garam yang akan terlarut kembali di laut sehingga meningkatkan salinitas lautan. Untuk salinitas 31-35 ppt masih dapat menopang kehidupan Echinodermata.

Kisaran $\mathrm{pH}$ hasil penelitian pada stasiun 1,2 dan 3 sebesar7-8. Nilai pH ketiga stasiun mendukung kehidupan biota laut yaitu 7-8,5 (Simatupang et al, 2017). Dengan demikian nilai pH pada masing-masing stasiun penelitian masih layak untuk kehidupan biota Echinodermata. Kondisi perairan yang bersifat sangat asam maupun sangat basa akan membahayakan kelangsungan hidup organisme karena akan menyebabkan terjadinya gangguan metabolisme dan respirasi. $\mathrm{pH}$ yang sangat rendah akan menyebabkan mobilitas berbagai senyawa logam berat yang bersifat toksik semakin tinggi yang tentunya akan mengancam kelangsungan hidup organisme akuatik (Novianti et al., 2016). Hasil pengukuran oksigen terlarut yang didapatkan pada setiap stasiun berbeda-beda. Kisaran DO yang didapatkan berkisar antara 4,7- 6,9. DO pada stasiun 2 memiliki nilai kisaran yang tertinggi dibanding stasiun 1 dan 3 . Hal ini diduga karena banyaknya tumbuhan rumput laut sehingga dapat memberikan pasokan DO yang tinggi di stasiun 2. Secara umum, kisaran DO pada lokasi penelitian masih dapat mendukukung kehidupan Echinodermata di ekosistem pantai Pok Tunggal karena DO masih pada kisaran baku mutu yaitu 4-8 mg/l (Martoyo et al., 2006).

\section{KESIMPULAN}

Berdasarkan hasil penelitian dapat disimpulkan bahwa: Echinodermata yang terdapat di pantai Pok Tunggal ada 5 jenis yaitu, Ophiocoma erinaceus, Ophiocoma dentata, Echinometra oblonga, Echinometra mathaei dan Echinothrix diadema. Jenis yang paling banyak ditemukan adalah E. oblonga dan yang paling sedikit adalah Echinometra mathaei dan Echinothrix diadema. Struktur komunitas Echinodermata di Pantai Pok Tunggal meliputi nilai indeks keanekaragaman $(H)$ berkisar antara 0,667-1,198, nilai indeks keseragaman (E) berkisar 0,744-0,999 dan nilai indeks dominansi $(\mathrm{C})$ berkisar antara 0,308-0,525. Pengukuran kualitas perairan menunjukkan bahwa kondisi perairan di Pantai Pok Tunggal masih menunjang kehidupan Echinodermata.

\section{DAFTAR PUSTAKA}

Arthaz, C.P, Suryanti, \& Ruswahyuni. 2015. Hubungan Kelimpahan Bulu Babi (Sea Urchin) Dengan Bahan Organik Substrat Dasar Perairan di Pantai Krakal, Yogyakarta. Management of Aquatic Resources Journal. 4(3): 48-155.

Aziz, A. 1996. Habitat dan Zonasi Fauna Echinodermata di Ekosistem Terumbu Karang. Oseana 21(2): 33-43.

Barus, T.A. 2004. Pengantar Limnologi Studi Tentang Ekosistem Air Daratan. Medan: USU Press. 187 hal.

Brotowidjoyo, M.D. 1994. Zoologi Dasar. Jakarta: Erlangga. 349 hal.

Brusca, R.C \& Brusca, G.J. 2003. Invertebrates. Sinauer Associates, Inc. Sunderland. USA.

Budiman, C.C., Maabuat, P.V., Langoy, M.L. \& Katili, D.Y., 2014. Keanekaragaman 
Echinodermata di Pantai Basaan Satu Kecamatan Ratatotok Sulawesi Utara. Jurnal MIPA, 3(2):97-101.

Damayanti, A. \& Ayuningtyas, R., 2008. Karakteristik fisik dan pemanfaatan pantai karst Kabupaten Gunungkidul. Makara Journal of Technology, 12(2):91-98.

Erlangga Y, Rahimi, S.A.E \& Devira, C.N. 2018. Struktur Komunitas Echinodermata di Perairan Pantai Gapang, Desa Iboih, Kecamatan Sukakarya Sabang. Jurnal IImiah Mahasiswa Kelautan dan Perikanan Unsyiah. 3(1): 92-101.

Fell, H.B. 1960. Synoptic Keys to The Genera of Ophiuroidea. University of Wellington, New Zealand.

Hickman, Larry, S., \& Allian, L. 2001. Integrated principles of zoology. Elevent Edition. New York: The McGraw-Hill. $473 \mathrm{p}$.

Martoyo, J., Aji, N. \& Winanto, T. 2006. Budidaya Teripang, Cet. 6, edisi revisi. Penebar Swadaya. Jakarta. 33 hal.

Novianti. M, Adun. R., \& Romdah, R. 2016. Keanekaragaman Jenis Echinodermata Pada Berbagai Macam Substrat Pasir, Lamun dan Karang di Perairan Pantai Sindangkerta Cipatujah Tasikmalaya. Jurnal Pendidikan Biologi. 4(1): 42-49.

Nugroho, P.E.R., Purnomo, P.W. \& Suryanti, S., 2018. Biodiversitas Echinodermata Berdasarkan Tipe Habitatnya Di Pantai Indrayanti, Gunungkidul, Yogyakarta. Management of Aquatic Resources Journal, 6(4):409-414.

Nybakken, J.W. 1992. Eidman HM, alih bahasa. Biologi laut suatu pendekatan ekologis. Jakarta: PT Gramedia Pustaka Utama. 459p.

Odum, E. 1993. Dasar-dasar Ekologi. Terjemahan T. Samingan. Yogyakarta: Gadjah Mada University Press. 174-185 hal.

Putri, A.E.M., Sunaryo, S. \& Endrawati, H., 2019. Perbandingan Jenis dan Jumlah Echinodermata Di Perairan Pantai Krakal Gunung Kidul Yogyakarta Dan Pantai Pailus Jepara, Jawa Tengah. Journal of Marine Research, 8(2):127-140. DOI : 10.14710/jmr.v8i2.25090

Radjab, A.W. 2001. Reproduksi dan Siklus Bulu Babi (Echinoidea). Oseana. HIm. Jakarta: LIPI. 25-36 hal.

Raghunathan, C., 2013. A guide to common Echinoderms of Andaman and Nicobar Islands. Zoological Survey of India. 695-769 p.

Ramawijaya, R., Awaludin, M.Y. \& Pranowo, W.S., 2012. Variabilitas Parameter Oseanografi Dan Karbon Laut Di Teluk Banten. Jurnal Perikanan dan Kelautan, 3(3):339-346.

Simatupang, M.Y.C., Sarong, M.A. \& Ulfah, M. 2017. Keanekaragaman Echinodermata Dan Kondisi Lingkungan Perairan Dangkal Pulau Pandang Kabupaten Batu Bara Provinsi Sumatera Utara. Jurnal IImiah Mahasiswa Kelautan dan Perikanan Unsyiah, 2(1):97-103.

Suryanti, R.O. \& Frida, P. 2014. Kelimpahan Echinodermata Pada Ekosistem Padang Lamun Di Pilau Panggang, Kepulauan Seribu, Jakarta. Management of Aquatic Resources Journal, 3(4): 243- 249.

Suwartimah, K., Wati, D., Endrawati, H., \& Hartati, R. 2017. Komposisi Echinodermata Di Rataan Litoral Terumbu Karang Pantai Krakal, Gunung Kidul,Yogyakarta. Buletin Oseanografi Marina, 6(1), 53-60. DOI : 10.14710/buloma.v6i1.15743

Syafrijal, S., Mukarramah, N. \& Ahadi, R 2019. Indeks Keanekaragaman Echinodermata di Perairan Pantai Desa Deudap Pulo Aceh Aceh Besar. Prosiding Seminar Nasional Biotik 2018, 5(1):397-401.

Triana, R., Elfidasari, D. \& Vimono, I.B. 2015. Identifikasi Echinodermata di selatan Pulau Tikus, Gugusan Pulau Pari, Kepulauan Seribu, Jakarta. Prosiding Seminar Nasional Masyarakat Biodiversitas Indonesia, 1(3):455-459.

Triatmojo, A., Ario, R., \& Widianingsih, W. 2018. Kelimpahan Echinodermata Pada Zona Intertidal di Pantai Krakal dan Pantai Kukup, Gunungkidul YogYakarta. Journal of Marine Research, 7(4), 263-272. DOI : 10.14710/jmr.v7i4.25925

Yusron, E. 2009. Keanekaragaman Jenis Echinodermata Di Perairan Teluk Kuta, Nusa Tenggara Barat. Makara Journal of Science, 13(1):45-78. 
Yusron, E. 2010. Keanekaragaman Jenis Echinodermata Di Perairan Likupang, Minahasa Utara, Sulawesi Utara. IImu Kelautan: Indonesian Journal of Marine Sciences, 15(2):85-90.

Yusron, E. 2015. Struktur Komunitas Ekhinodermata (Holothuroidea, Echinoidea dan Ophiuroidea) di Daerah Padang Lamun di Pantai Gunung Kidul, Yogyakarta. Zoo Indonesia. 24(2): 73- 82. 